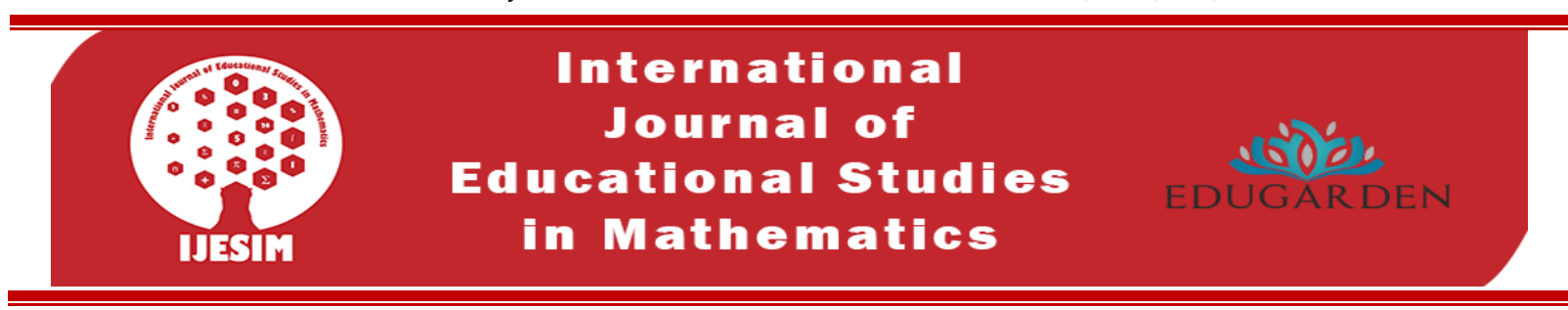

\title{
Examining the Use of Expanded Discourse: Treatments of Secondary School Mathematics Teachers' and Preservice Teachers' the Correct Answer
}

\author{
Şeyma Erkoç ${ }^{1,2}$, Sebahat Yetim Karaca ${ }^{2}$
}

${ }^{2}$ Gazi University, Faculty of Education, Ankara, Turkiye

\begin{tabular}{l}
\hline \hline A B STR ACT \\
The purpose of the study is to examine the extended discourse formed by \\
secondary school mathematics teachers and preservice mathematics \\
teachers in response to the correct answers given by secondary school \\
students to the questions and to reveal whether there is a difference in the \\
expanded discourse styles used by teachers and preservice teachers. The \\
research is a case study; which is one of the qualitative research methods. \\
A measurement form consisting of five correct response scenarios has been \\
developed by the researchers through literature review, and the final form \\
has been given by expert view. Correct answer scenarios have been limited \\
by numbers learning area. Finalized measurement tool has been applied to \\
nine teachers and ten preservice teachers. The qualitative data obtained \\
have been analyzed by content analysis method. According to the results \\
of the analysis, it has been determined that when students give the correct \\
answer to the questions, teachers create a discourse environment by using \\
the types of intervention such as asking students to make more \\
explanations, reward system, asking for different solutions. On the other \\
hand, it has been revealed that the preservice teachers preferred to use the \\
method of forming classroom discussions as well as asking teachers to \\
make explanations, reward system, and asking for different solutions \\
while considering the correct answers of students. It is observed that \\
teachers mostly choose methods appropriate to teacher-centered \\
traditional teaching strategies, while preservice teachers generally use \\
methods appropriate to student-centered research and analysis strategy. \\
Besides, it has been determined that while teachers generally preferred to \\
use a single method, preservice teachers generally used more than one \\
method.
\end{tabular}
ARTICLE INFO

\section{Article History:}

Received:18.10.2020

Received in revised form:01.12.2020

Accepted:02.12.2020

Available online: 23.12 .2020

Article Type: Standard paper

Keywords: mathematical discourse, expanded discourse, types of intervention, correct answer

\section{Introduction}

Until today from the declaration of the Turkish Republic, when the elementary school mathematics curriculum, which have been organized according to the needs and expectations of the relevant period, have been examined with an overview; it is seen that the changes in the mathematics lesson programs as a result of the program development efforts made before the 2005 Mathematics Teaching Program are related to the content. In some of the programs before the year 2005 change, concepts or discourses such as active student participation, problem solving skills, and the use of activities have been encountered, but it has been observed that these programs adopted a behavioral approach in practice (Sezgin Memnun, 2013). In our country, in 2005, the elementary education mathematics curriculum has been developed according to the constructive learning theory and is being 
implemented with ongoing updates until today. In this context, constructivist learning approach, which is a very important transformation, is also considered very important for mathematics education. When the approach is examined, it was seen that it has given great responsibilities to the teacher and the student, and it has many important characteristics, such as being effective, efficient, permanent, and performance-based.

It has been stated that the purpose of the evaluation in the secondary school mathematics (5th, 6th, 7th and 8th grades) curriculum (MoNE, 2013) is "... to help students evaluate themselves, to get information about student development and learning process and to perform a better education in the light of these..." Besides, while explaining the principles for teaching approaches in the program, it has been emphasized that feedback should be given to students with expressions like "Feedback supportive to learning should be given." (cited by Köğce and Adnan, 2014).

Inquiry of the teacher affects children's learning opportunities and thoughts. Therefore, educators need to understand how they use inquiry and realize what type of questions lead to what kind of results (Weinberger, 2017).The teacher, who is the provider of the mathematical discourse environment, must have the competence to develop this skill and must follow the necessary knowledge, skills, equipment, materials, technological and scientific developments (Bingölbali, Akkoç, Özmantar and Demir, 2011).

Schleheppenbach, Perry, Miller, Sims, and Fang (2007a) explained the concept of expanded discourse by stating that their students' answer to a question is only a beginning. According to these scientists, expanded discourse serves to create a platform of the mathematical algorithms, rules, and reasoning processes that a student needs to find the answer to a question. A model application regarding the expanded discourse presented in his research is as follows:

Teacher: What's the answer?

Student: The fraction of $5 / 8$ is equal to the fraction of $40 / 64$.

Teacher: Why did you do like that?

Student: If the number 5 is multiplied by 8 , it is equal to 40 , that's why the number 8 is multiplied by the same number, and 8 times 8 equals to 64 .

Teacher: How can you explain simpler? Both numerator and denominator ...

Students (altogether): Multiply by 8.

As seen in the example above, Schleheppenbach et al. (2007a), in this study, creates an expanded discourse environment by asking questions which will reveal the way of thinking for going to the correct answer, even though the student gave the correct answer. In another study of Schleheppenbach et al. (2007b), in which they studied the types of intervention against student mistakes by teachers, they determined the following categories as a result of the analysis of in-class training practices:

- Telling the student that their answer was wrong,

- Giving the correct answer,

- Negligence of the mistake,

- Making a statement or providing guidance,

- Repeating the question,

- Clarifying the question,

- Asking different thoughts for the answer to the question

- Asking if there are students participating to the answer or the explanation.

Teacher should have strong subject matter knowledge about the content of the subject and be able to understand that the student generates ideas outside of the conventional ways. Teachers often make didactic decisions based on the ideas and actions put forward by the students in the previous lessons (Martino and Maher, 1999). Developing appropriate inquiry techniques is an important part of mathematics teaching and assessment (Moyer and Milewicz, 2002). Student dialogues are important element of classroom discourse and important tool that enhances students' learning. The mathematical 
discourse environment, which is formed as a result of the inquiry environment created by teachers in mathematics lessons that supports students' explanations, reveals information that will constitute a source for teaching decisions (Franke, Webb, Chan, Ing, Freund and Battey, 2009).

Besides being interested in the results obtained by students mathematically, teachers should try to learn the path the students followed to achieve this result (Crespo, 2000). Feedback messages with detailed explanations in addition to the correct answer are an effective way to improve students' learning. Feedbacks that provide the explanation of the correct answer are used to improve students' learning by using these explanations in new problems they encounter (Butler, Godbole and Marsch, 2013).

The teaching skill of the teacher is not only related to how they reflect their subject matter knowledge to teaching, it is also related to various fields of knowledge such as knowledge of teaching strategies, student knowledge, schedule knowledge. Teachers' ability to make effective questioning reflects on student knowledge acquisition. Teachers who make effective questioning in revealing students' thoughts can go deep into students' thoughts and analyze students' answers well, and properly evaluate what students know and think (Tanışl1, 2013). One of the basic duty of teachers is to analyze students' thoughts and contribute to improve student practices. In addition to that, providing the formation of basic knowledge regarding the mathematical thinking development of students is another crucial duty of teachers. (Martino and Maher, 1999). Teachers' use of questioning technique improves students' academic success and upgrades comprehensibility (McCarthy, Sithole, McCarthy, Cho and Gyan). The students' efforts to understand, the questions they ask, and alternative solutions developed in relation to find a way out in class create an opportunity for the development of critical thinking skills. At the same time, creative thinking skills are being improved in students who can develop detailed ideas against the questions (Özmantar, Bingölbali, Demir, Sağlam and Keser, 2009). The expression of mathematical thoughts takes place through mathematical discourses formed inclass. The appropriate discourse environment in the mathematics teaching process directly affects the student's attitude towards mathematics, their perspective and ultimately their success (Genç and Erdem, 2016). The modern understanding of mathematics education requires the transition from teacher-centered learning environments to learning environments that focus on the development of students' mathematical thinking and reasoning skills and the ability to actively participate in mathematical discourses, and requires mathematics teachers to have knowledge and skills in subjects such as discourse development and management of mathematical discourses (Kabael and Ata Baran, 2016). The discourse that teachers will form towards the students' answers is important to upgrade students' understanding of the subject and advancing mathematics achievement. That's why, intervention to the correct and wrong answers given by students causes important consequences in terms of education and training. In this context, the purpose of the study is to determine the expanded discourse styles of secondary school mathematics teachers and preservice mathematics teachers formed by students' correct answers, and to reveal whether there is a difference in the expanded discourse style used by teachers and preservice teachers.

\section{Method}

The purpose of this study is to determine the types of interventions of secondary school mathematics teachers and preservice mathematics teachers to correct answers of students and to reveal whether there is a difference in the types of intervention of teachers and preservice teacher. The qualitative research method has been preferred because the types of intervention of teachers, which is an existing situation within the scope of the study, has been tried to be revealed. Qualitative studies are studies in which qualitative data collection methods such as observation, interview and document analysis are used, and a qualitative process is followed to reveal perceptions and events in a realistic and holistic manner in the natural environment (Yıldırım and Şimşek, 2013). Among the qualitative research designs, case study has been preferred. The main purpose of case studies is to make detailed descriptions about a situation and to understand that situation as it exists (Büyüköztürk, Kılıç Çakmak, Akgün, Karadeniz and Demirel, 2014). 


\subsection{Study Group}

The purposeful sampling technique, born entirely within the qualitative research, has been used in determining the participants in the study. Purposeful sampling is a technique that emerged entirely within qualitative research, in contrast to probability-based sampling methods developed within the quantitative research tradition but used in a limited way by qualitative researchers (Yıldırım and Şimşek, 2013, p.135). The rationale of the purposeful sampling is to choose more knowledgeable participants in order to conduct the research deeply. In this study, the criterion sample, one of the purposeful sampling types, has been determined by the participants. The basic understanding in the criterion sample is to study all situations that countervailing a predetermined set of criteria (Yildırım and Şimşek, 2013, p.135). Accordingly, the participants of the study are 9 teachers and 10 preservice teachers.

\subsection{Data Collection Tool}

The data collection tool has been developed by the researchers by making literature review and asking expert opinion. Since it is the learning area with the most gains in the mathematics curriculum and suggested by the experts; the research is limited to the "numbers" learning area. In the developed measurement tool, dialogues between students and teachers in-class environment and real environment scripts have been created and it has been aimed to examine what kind of learning environment teachers created in the rest of the scenarios. The scripts have been prepared for the correct answer in accordance with the purpose of the research. There are five correct answer scripts about the numbers learning area in the measurement tool. Table 1 shows the grade level and the learning outcome for each question.

Table 1: Acquisitions taken as a basis while preparing the questions in the measurement tool.

\begin{tabular}{|c|c|c|}
\hline Question Number & Grade Level & Learning Outcome \\
\hline 1 & 5th Grade & $\begin{array}{l}\text { M.5.1.3.4. Understands that simplification and expansion will not change } \\
\text { the value of the fraction, and creates fractions that are equivalent to a } \\
\text { fraction. }\end{array}$ \\
\hline 2 & 5th Grade & M.5.1.2.12. Solves problems involving four operations. \\
\hline 3 & 5th Grade & $\begin{array}{l}\text { M.5.1.2.4. Can make the multiplication of two natural numbers with three } \\
\text { digits at most. }\end{array}$ \\
\hline 4 & 5th Grade & $\begin{array}{l}\text { M.5.1.2.1. Performs the addition and subtraction of natural numbers with } \\
\text { up to five digits. }\end{array}$ \\
\hline 5 & 7th Grade & M.7.1.1.5. Solves problems that require operations with integers. \\
\hline
\end{tabular}

\subsection{Analysis of Data}

The qualitative data collected within the scope of the research has been analyzed by content analysis. Content analysis provided an in-depth analysis of the qualitative data collected, allowing general categories to be reached as a result of these examinations. In this context, the answers given by the teachers and preservice teachers have been examined deeply and the structures with similar content have been classified under the same category titles. Then, the frequencies of the categories formed by the teachers and preservice teachers for each question have been presented with the help of graphics.

\section{Findings and Interpretation}

Within the scope of the study, the responses of teachers and preservice teachers to five different correct answer scripts have been examined deeply, and categories have been created by considering the types of feedback, intervention and inquiry within the literature. Teachers and preservice teachers can use more than one type of feedback, intervention and inquiry in the script. The types of interventions determined to be used by teachers and preservice teachers as an intervention to the correct answer in scripts aimed at creating an expanded discourse environment in the study and what kind of teacher-preservice teacher behaviors these intervention types correspond to are explained in Table 2. 
Table 2: Categories created in the study and teacher- preservice teacher behaviors belonging to these categories.

\begin{tabular}{|c|c|}
\hline Categories & Teacher-Preservice Teacher Behaviors \\
\hline Making a statement & $\begin{array}{l}\text { The teacher explains directly to the class what the student has done } \\
\text { after the students give their answer }\end{array}$ \\
\hline Asking to explain the answer & $\begin{array}{l}\text { Explain directly why the students chose such an action after they give } \\
\text { their answers }\end{array}$ \\
\hline Reward & $\begin{array}{l}\text { Stating that the answer is correct, using expressions such as "well } \\
\text { done", asking for applause by the class, giving a small gift }\end{array}$ \\
\hline Generating a class discussion & $\begin{array}{l}\text { Providing a discussion environment with the class about the stages of } \\
\text { the process by asking questions to the students in the classroom based } \\
\text { on the student's answer }\end{array}$ \\
\hline Showing a Different Way of Solution & of solu \\
\hline Questioning & $\begin{array}{l}\text { Asking questions about why and what for the student performed the } \\
\text { steps of the procedure, analyzing the student's answer with questions } \\
\text { that reveal different opinions. }\end{array}$ \\
\hline Asking a Different Way of Solution & Asking the student or the class if it could be done differently \\
\hline Asking Questions & $\begin{array}{l}\text { Asking the student directly about the steps of the process they perform } \\
\text { while looking for the answer. For example, "Why did you subtract } 2 \\
\text { out of } 4 \text { ?" etc. }\end{array}$ \\
\hline $\begin{array}{l}\text { Asking other students for their } \\
\text { solutions }\end{array}$ & $\begin{array}{l}\text { After the answer given by the student, saying that the answer is correct } \\
\text { and listening to the solutions of the students who did it in a different } \\
\text { way. }\end{array}$ \\
\hline Giving an example & $\begin{array}{l}\text { Explaining the student's solution by giving another example similar to } \\
\text { the question in the script. }\end{array}$ \\
\hline Verification & Checking by asking the student to show the accuracy of their answer \\
\hline
\end{tabular}

When Table 2 is examined, it is seen that the answers that the teacher explains directly to the class what the student has done after the student answers, are considered in the "making explanation" category. Participant responses exist in the "Asking to explain the answer" category, to which the student has been asked to explain directly why they chose such an action after giving their answer, in the "Reward" category congratulating the student by stating that the answer is correct, using expressions such as "well done", asking for applause by the class, giving a small gift. Participant responses in the category of "Creating a class discussion" have been determined to provide a discussion environment with the class about the steps of the process by asking questions to the students in the classroom based on the answer given by the student. Participant responses in the "questioning" category aim to ask questions about why and what for the student did the steps of the procedure, and to analyze the student's answer with questions that will reveal different opinions. In the category of "Asking a Different Solution", participant responses, which mean asking the student or the class if they can be done in a different way, on the answer of the student, and in the "Asking Question" category, participant responses that mean asking questions directly to the student about the steps of the process while looking for the answer have been discussed. After the answer given by the student, the participant responses that include listening to the solutions of the students who found the answer in different ways by saying that the answer was correct: "Asking the other students for their solutions", the participant responses tending to explain the student's solution by giving another example similar to the question in the script, "giving an example" and asking the student to show the correctness of their answer. Participant responses to having it done have been evaluated in the category of "Providing".

The first of the correct answer scripts deals with the fifth grade fractions issue. The script is given in Figure 1 below. 
In the $5^{\text {th }}$ grade secondary school mathematics lesson, the teacher draws the figures A and B representing the same whole on the blackboard as shown below.

A

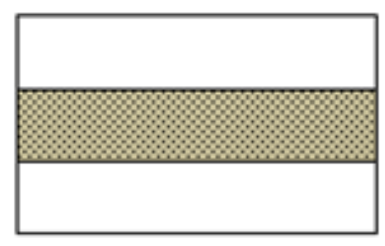

B

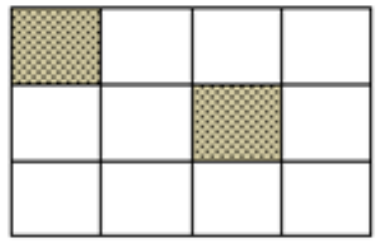

In the figure $A$, the shaded region represents one third of the whole, while in figure $B$, a shaded square represents one twelfth of the whole. The teacher asks the question of how many squares should be shaded in figure $B$ so that the fractions displaying the shaded regions of figures $A$ and $B$ are equivalent. A student named Elif answered this question as below:

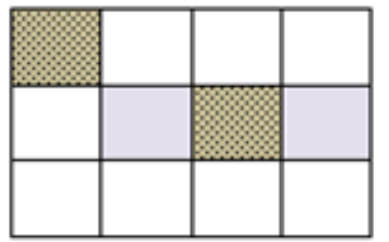

If you were Elif's teacher, how would you assess Elif's answer in the classroom? Please explain.

Figure 1: Correct answer script 1.

Two teachers left the answer for this script blank. In line with the responses given by the teachers and preservice teachers, categories related to the types of intervention have been created. The categories obtained are given in Figure 2.

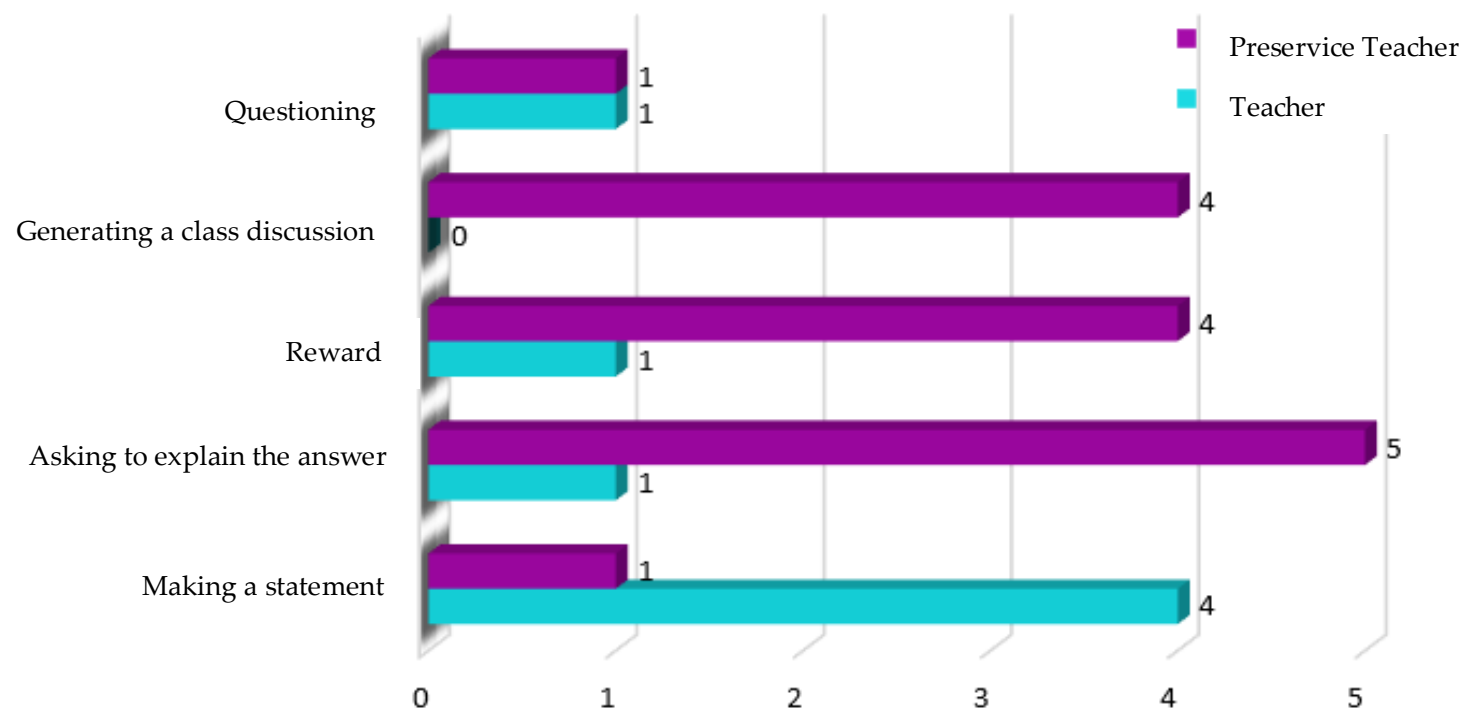

Figure 2: The types of interventions obtained in line with the responses given to the Correct Answer Script 1.

When Figure 2 is examined, it is seen that teachers use the "making explanation" method, in which they try to explain the student's operations upon the answer given as the type of intervention. It is seen that preservice teachers mostly use methods of asking students to explain the answer, reward 
system by congratulating or asking the class to applaud, and creating a classroom discussion environment by taking the opinions of the class about the answer. A teacher and a preservice teacher mentioned a type of intervention aimed at making the student question whether a different solution could be found by showing different equivalences. It is observed that teachers mostly choose the types of intervention in line with traditional teaching strategies, while teacher candidates mostly use the types of interventions that are in line with the research and analysis strategy. Besides, it has been determined that while teachers generally preferred to use one type of intervention, preservice teachers generally used more than one type of intervention. Some of the answers given by the teachers and preservice teachers are given below.

TEACHER 4: I would make two kinds of explanations.

Explanation I: We indicate that $\mathrm{A}$ is $1 / 3$, and B is divided into 12 equal parts, so if we expand it by 4

$$
1 / 3=1 \times 4 / 3 \times 4=4 / 12
$$

Then if $B$ is $2 / 12$ then 2 more parts should be shaded so that we get $4 / 12$. So Elif's answer is correct.

Explanation II: We can draw perpendicular lines to divide A into 12 like B . 4 pieces shaded in the same way. If we shade 2 parts in B, they become equal.

PRESERVICE TEACHER 1: Elif's answer is also correct. But what others think in the classroom is also important. What they mean is also important I generate discussion with other results. We show that it doesn't matter how you choose the piece from the whole.

The second of the correct answer scripts is about four operations in fifth grade natural numbers. The script is given in Figure 3 below.

Teacher writes the question below on the black board in a Math class for $5^{\text {th }}$ grade students.

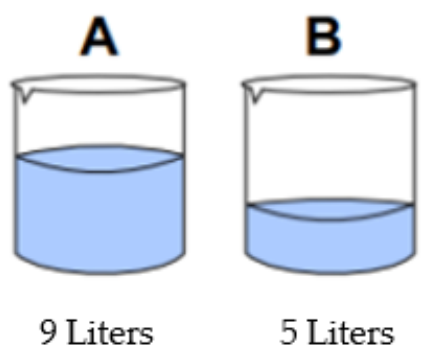

Bucket A has 9 liters of water, and Bucket B has 5. In order to level the amount of water inside each bucket, how many liters of water should be transferred from which bucket to the other?

A student named Deniz performs the calculation:

$$
\begin{aligned}
& 9-5=4 \\
& 4: 2=2
\end{aligned}
$$

If you were the teacher of Deniz, how would you assess this answer in the classroom. Please explain.

Figure 3: Correct answer script 2. 
All participants responded to this script. In line with the responses given by the teachers and preservice teachers, categories related to the types of intervention have been created. The categories obtained are given in Figure 4.

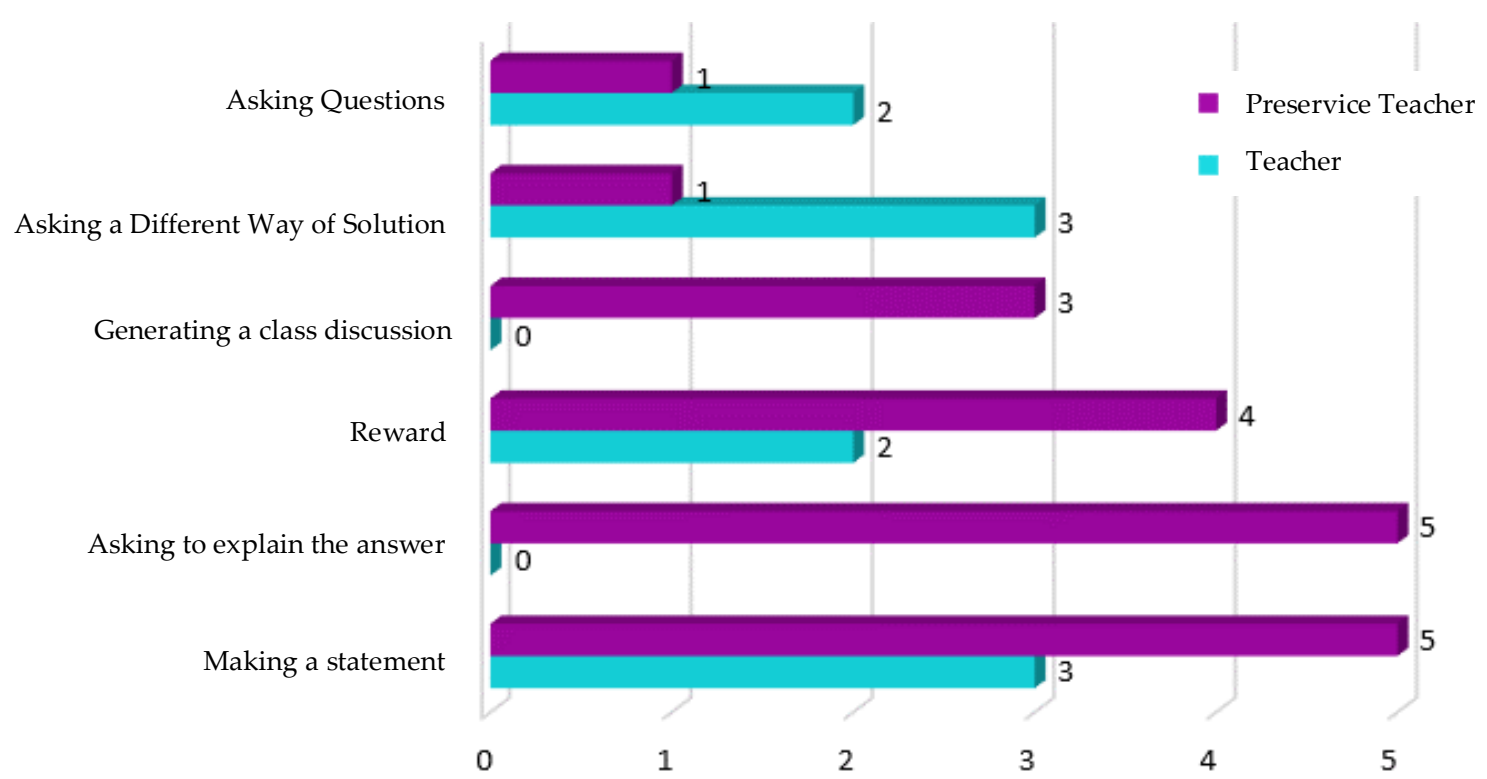

Figure 4: Types of intervention obtained in line with the answers given to the correct answer script 2.

When Figure 4 is examined, it is seen that 3 of the teachers use the intervention type of making explanation, 2 of them using reward method, 3 of them using different solution way questions, 2 of them asking questions. Addedly, even though the answer of the student given in the script was correct, one of the teachers thought that the answer was incorrect because of the student's way to reach the correct answer and asked the student to do it according to the way he was taught. This shows that the teacher is not open to different solutions developed by the students. The teacher's answer is given below.

TEACHER 5: I would emphasize that he should divide the total into two equal parts. Accordingly, I would make the necessary directions so that they can solve the question correctly.

When the preservice teachers were examined it was determined that in line with their responses to the second answers; 5 preservice teachers made explanations, 5 preservice teachers asked students to explain their answers, 4 preservice teachers have chosen reward system, 3 preservice teachers created classroom discussions, 1 preservice teacher asked different solutions and 1 preservice teacher used the intervention types. While teachers generally prefer to use one type of intervention, preservice teachers prefer to use more than one type of intervention. Some of the answers given by the teachers and preservice teachers are given below.

TEACHER 7: I ask why he did the subtraction. Then I examine the reason for doing the extraction. I also give time to consider if there is a different solution.

PRESERVICE TEACHER 2: I would like him to explain the solution. I would try to understand the steps and what he thought while he was solving the problem. I listen to the solutions of other students in the class.

The third of the correct answer scripts is about the issue of multiplying the fifth grade natural numbers. The script is given in Figure 5 below. 
Teacher writes the multiplication operation below on the black board in a Math class for $5^{\text {th }}$ grade students.

$$
\begin{array}{r}
322 \\
\times \quad 80
\end{array}
$$

A student named Akif performs this multiplication as below:

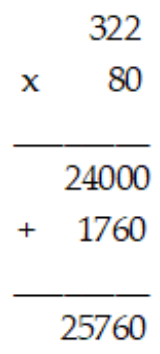

If you were Akif's teacher, how would you assess Akif's answer? Please explain.

Figure 5: Correct answer script 3.

A preservice teacher left the answer about this script blank. In line with the responses given by the teachers and preservice teachers, categories related to the types of intervention have been created. The categories obtained are given in Figure 6.

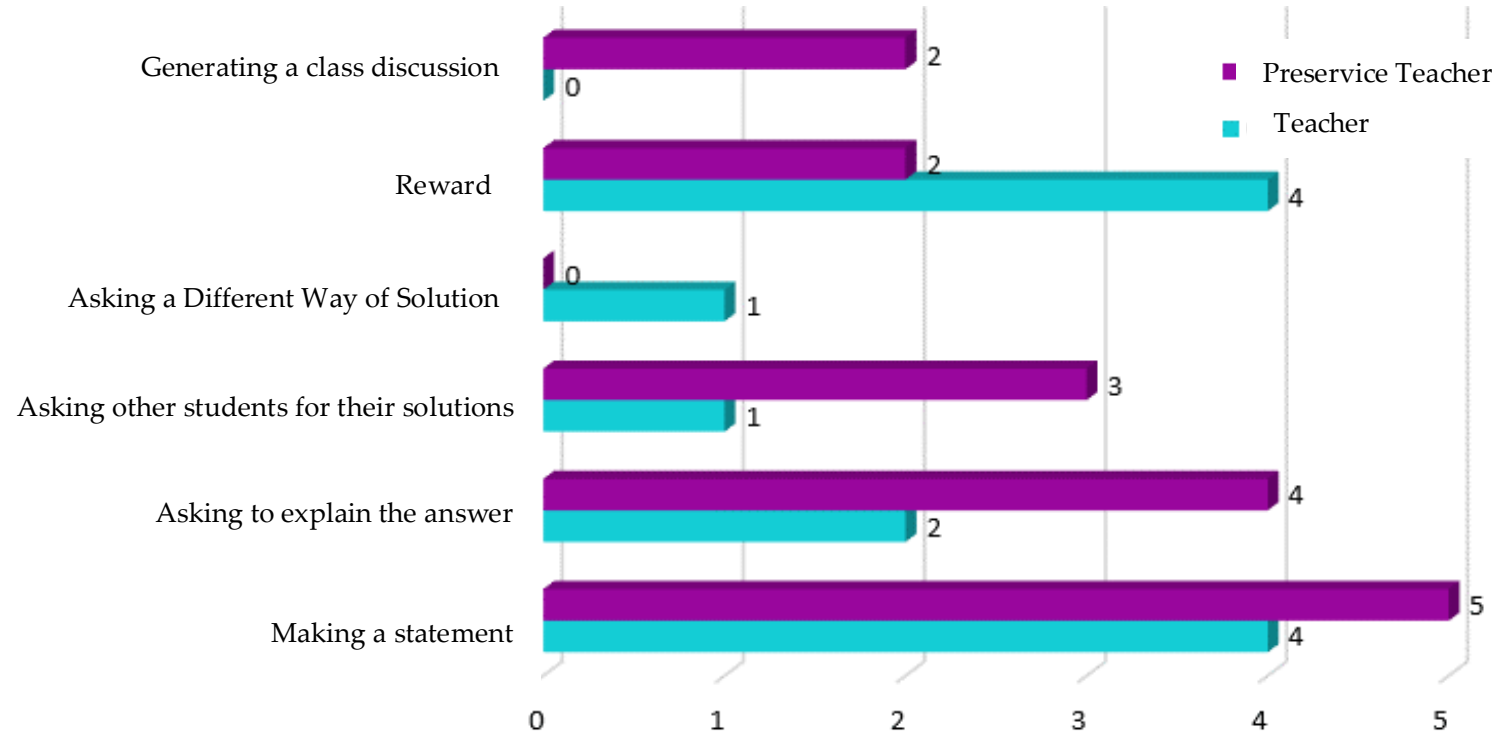

Figure 6: Types of intervention obtained in line with the answers given to the Correct Answer script 3.

When Figure 6 is examined, it is seen that in this script, teachers use intervention types of further explanation, asking to explain the answer and reward. It has been determined that preservice teachers used intervention types such as making explanations, asking for answers and reward system, as well as asking other students for solutions and creating class discussions. Some of the answers given by the teachers and preservice teachers are given below.

TEACHER 4: I would remind that we do the multiplication by paying attention to the digit values and summarize the operation to the class as follows.

322x80 (3 hundreds Digit, 2 tens Digit, 2 Units Digit) 


$$
\begin{aligned}
& 2 \times 80=160 \\
& 20 \times 80=1600 \\
& 300 \times 80=24000
\end{aligned}
$$

PRESERVICE TEACHER 4: I would ask why the student thinks that way. I ask the opinion of their friends. I would say the result was correct and ask him to explain the different strategy he used in solving the problem.

The fourth of the correct answer script is concerned with the fifth grade natural numbers four operation subjects. The script is given in Figure 7 below.

Teacher asks the question below in a Math class for $5^{\text {th }}$ grade students:

"Write three numbers whose sum is equal to $5000 . "$

A student named Mehmet gives the answer as:

$$
500,2500 \text { and } 2000
$$

If you were Mehmet's teacher, how would you assess Mehmet's answer in the classroom?

Please explain.

Figure 7: Correct answer script 4 .

Seven teachers left the answer for this script blank. In line with the responses given by the teachers and preservice teachers, categories related to the types of intervention have been created. The categories obtained are given in Figure 8.

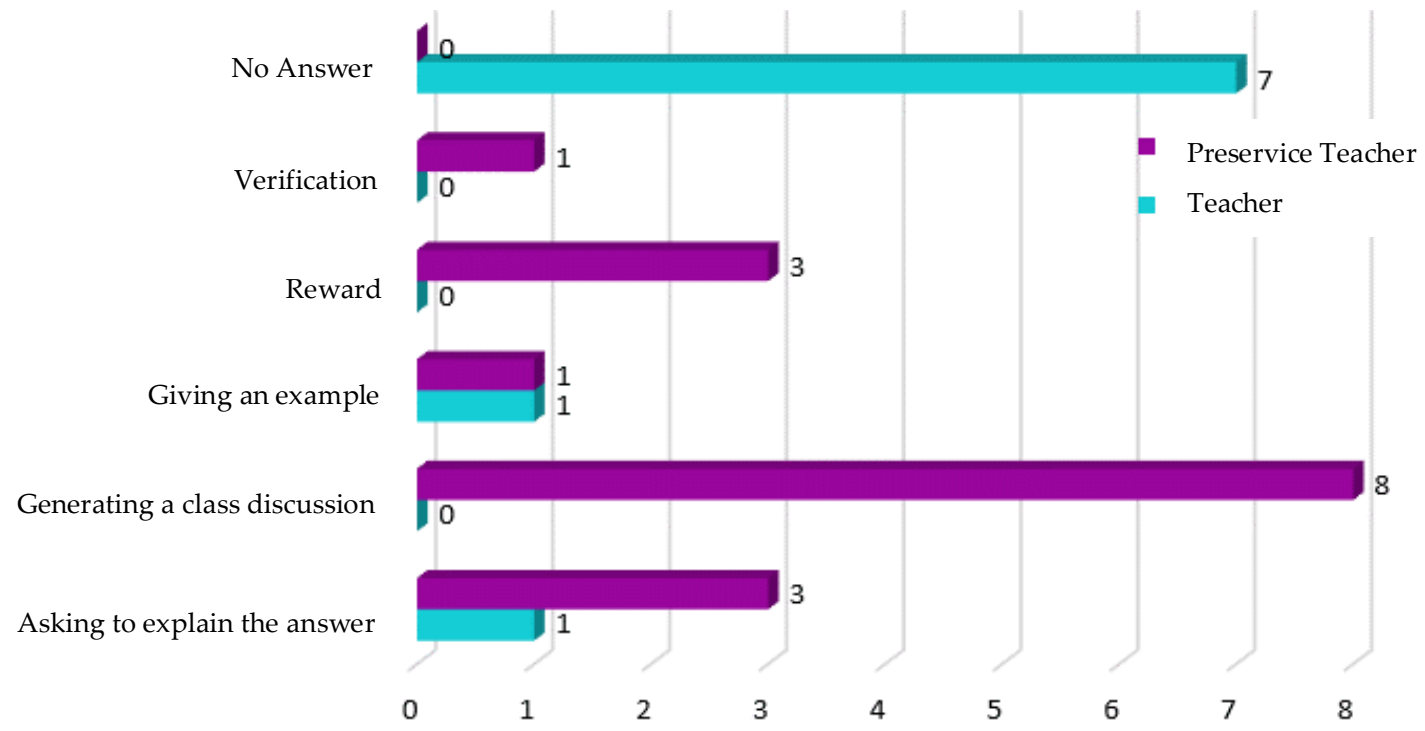

Figure 8: Types of intervention obtained in line with the answers given to the correct answer script 4 .

When Figure 8 is examined, it is seen that most of the teachers did not answer for this script. One of the two teachers who responded to this scenario asked the student to explain his answer, and the other used the exemplary intervention type. Most of the preservice teachers stated that in this scenario, they would create a class discussion as a type of intervention. Some of the answers given by the teachers and preservice teachers are given below.

TEACHER 2: I would ask why they chose these numbers; I would say they did it right.

PRESERVICE TEACHER 4: I would ask why they chose these numbers. I would ask the opinion of their friends. I would generate a discussion. I would ask if we could write other numbers. I would 
also write different trilogy combinations on the board with the help of students. Or I would have it written by students.

The fifth of the correct answer scripts is concerned with four processing topics in seventh grade integers. The script is presented in Figure 9 below.

Teacher writes the question below on the black board in a Math class for $7^{\text {th }}$ grade students:

"In a freezer that is just started to run, the inside temperature starts to fall $6^{\circ} \mathrm{C}$ for every passing hour. The initial temperature of the freezer is $+3^{\circ} \mathrm{C}$. After 4 hours, what will be the temperature of the freezer?

A student named Akif answers this question as below:

$$
\begin{array}{cc}
\text { End of } 1^{\text {st }} \text { hour: } & 3-6=-3 \\
\text { End of } 2^{\text {nd }} \text { hour: } & -3-6=-9 \\
\text { End of } 3^{\text {th }} \text { hour: } & -9-6=-15 \\
\text { End of } 4^{\text {th }} \text { hour: } & 15-6=-21
\end{array}
$$

If you were Akif's teacher, how would you assess Akif's answer in the classroom? Please explain.

Figure 9: Correct answer script 5.

All participants responded to this script. In line with the responses given by the teachers and preservice teachers, categories related to the types of intervention have been created. The categories obtained are given in Figure 10.

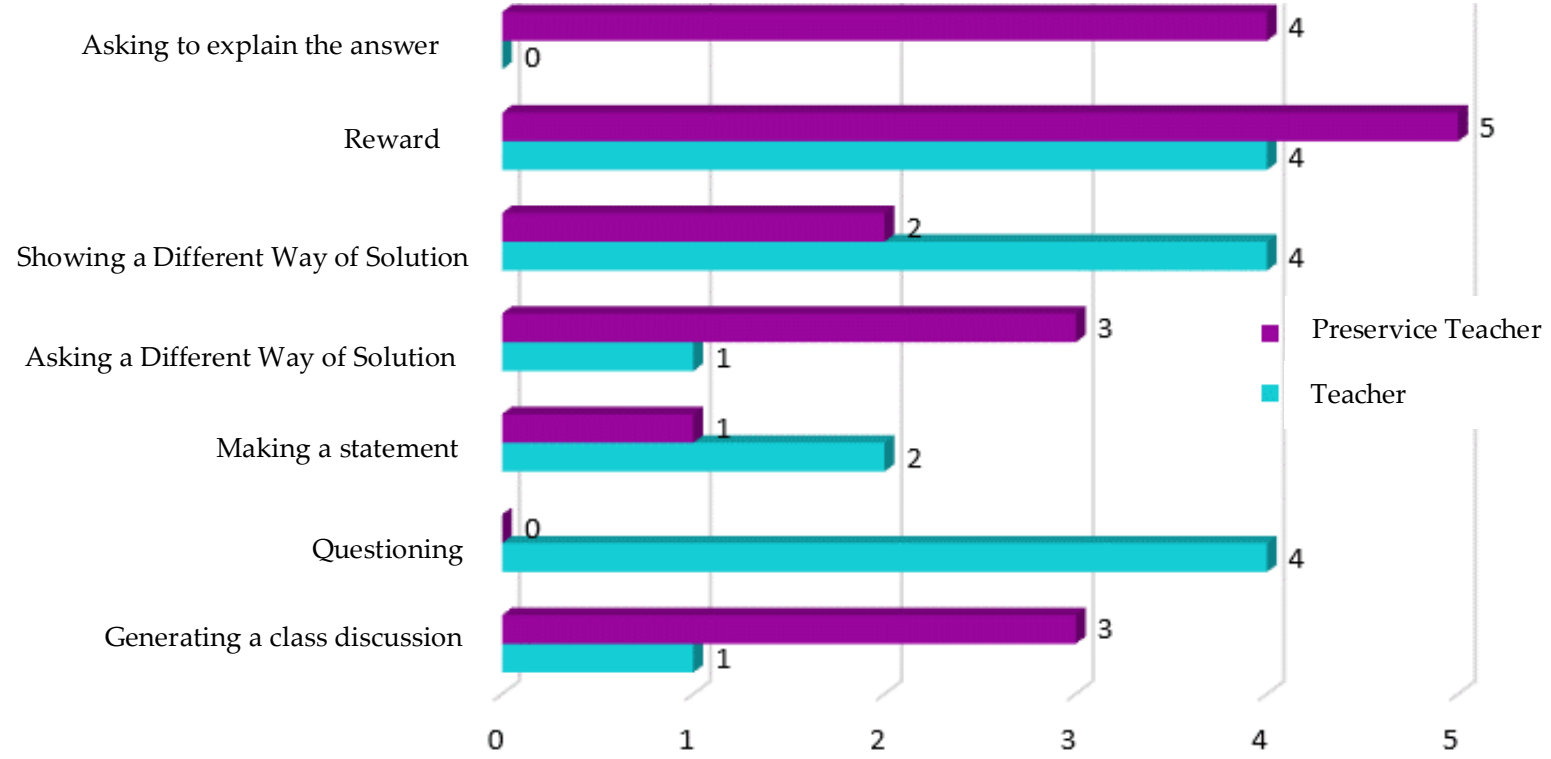

Figure 10: Types of intervention obtained in line with the answers given to the correct answer script 5.

When Figure 10 is examined, it is seen that teachers use intervention types such as more questioning, showing different solutions and rewards in this script. Preservice teachers mostly use intervention types such as rewards, asking for an answer, class discussion and asking for different solutions. Some of the answers given by the teachers and preservice teachers are given below. 
TEACHER 4: First of all, I would congratulate the student for creating the correct pattern for the solution and not making any transaction mistakes. I would tell the class that their friend reduces the temperature per hour. But I would ask what they would do if a longer period, such as 11 hours, was specified. I would ask them to think if there was a shorter way, and I would point out that they could do a second solution by pointing out the decrease by 6 degrees per hour, $4 \times 6=24 \mathrm{C}$ will decrease and will be $3-24=-21$.

PRESERVICE TEACHER 1: I would discuss the result with the class. When I think that my solution is correct, I generate a discussion for other ideas to emerge, and different ideas can be more meaningful for students who do not understand this solution.

PRESERVICE TEACHER 2: I would ask other students how they solved it. I would like them to describe the solution steps and how they thought. I would let the students see different solutions and explain it myself. (The preservice teacher did the same process with a little more explanation)

\section{Discussion and Conclusion}

As a result, it has been determined that teachers mostly used the types of correct answer intervention to ask for explanations, reward system, and asking for different solutions. Cimer, Bütüner and Yiğit (2010) determined in their studies that teachers they generally exhibited the behavior of reward system in a positive and evaluative way. This result supports this finding obtained within the scope of the research. McCarthy, Sithole, McCarthy, Cho, and Gyan (2016) had determined that teachers directed students to mathematical discourse instead of directly telling the answers, but they sometimes gave up questioning strategies and made more explanations for teaching concepts.

Another result of the study is that teachers are not open to different solutions developed by students. It is seen that in the right answer scripts in which the students have unconventional, non-rule based solutions, teachers generally leave blank without comment on that script. Moreover, in the right answer script 2, which shows a student who get the correct answer in a different way, a teacher telling the student's answer was wrong and explaining it his own way indicates that teachers are not open to different solutions that do not fit the rules. Şengül and Dede (2014) found that mathematics teachers were inadequate to use the concept of number sense for solving questions in different ways. This situation coincides with the finding of teachers' not being open to different solutions. Özmen, Taşkın and Güven (2012) determined that primary school mathematics teachers preferred more verbal, short and non-numerical problems, they used curriculum-dependent and routine problems more predominantly, which are irrelevant and do not contain incomplete data in terms of content, and preferred the types of problems that are easy and contain less processing in the solution structure. This finding supports the finding of the teachers obtained in this study not to be open to different solutions, as it shows that the teachers generally adhere to certain solutions and they hesitate to ask questions that will lead to original and different solutions.

It has been revealed that preservice teachers besides preferring to use intervention types like teachers such as asking to make explanations, reward system, asking for different solutions, and using the method of generating discussion is widely preferred by most pre-service teachers. Tanışlı (2013) found that preservice teachers had the opportunity to practice and develop their own questioning techniques by interacting with students before questioning in a classroom environment. This situation coincides with the finding that the students developed their own questioning skills by interacting with the students, by asking the students to make explanations and asking different solutions. Nevertheless, Baki, Güç and Özmen (2012) determined in their study that preservice teachers focused on solving the problem given in the process of problem solving in the shortest way, and could not respond adequately to the instructions they encountered regarding the dimensions of questioning the problem, reasoning and evaluating the solution stages. On the other hand, Bütün and Baki (2019), in their study with preservice teachers to see the development in three different times, determined that the preservice teachers initially only used approaches based on showing the way of processing in their explanations, while their explanations towards the end of the process were in the form of approaches based on showing the meaning of the problem. This finding supports the findings of the study which it reveals that the preservice teacher dealt with the questioning point of view of students to 
understand the problem deeply. This finding is supported by the finding obtained in the study by Türkdogan (2011) that preservice teachers used feedbacks such as ignoring the mistake, simplifying and associating it, saying the direct answer, saying the wrong, and leading to questioning by creating contradictions.

It is observed that teachers mostly choose the types of interventions appropriate to traditional teaching strategies, while it is observed that preservice teachers generally use the types of interventions appropriate to the research and analysis strategy. Additionally, it has been determined that teachers generally prefer to use one type of intervention, while preservice teachers use more than one type of intervention. Training of preservice teachers according to the changing curriculum in 2006 may have been effective in their use of various and different methods.

\section{Suggestions}

It has been concluded that the teachers, who generally used intervention methods for traditional methods, preferred the methods for the constructivist approach. This situation is thought to be due to the training of prospective teachers with the changing mathematics curriculum. Within the framework of the results obtained, it is recommended to prepare in-service training programs for new approaches for teachers in order to adapt teachers to changing curricula. Şahin (2011) concluded that with the professional development practice, teachers increased their awareness of the difficulties they faced and increased the number of interventions and types. In addition, it has been observed that the teacher candidates tried to create richer expanded discourse environments by using more than one intervention type together. The reason why teachers usually chose one type of intervention while the majority of preservice teachers preferred more than one type of intervention, is thought to be due to the fact that preservice teachers do not have a worry for the problem of covering the subjects in the real environment due to their lack of field experience. At the same time, the fact that contemporary teaching methods take more time may be a reason why teachers do not prefer these methods. Teachers who have difficulties in training in the intensive curriculum may also tend to prefer a more traditional method in the types of intervention. Therefore, it is recommended to field experts and policy makers to make the necessary arrangements in the program in order for teachers to create more efficient and meaningful lesson environments by giving more time to the types of intervention.

\section{References}

Baki, A., Gü̧̈, F. A., \& Özmen, Z. M. (2012). İlköğretim matematik öğretmeni adaylarının problem çözmeye yönelik yansıtıcı düşünme becerilerinin incelenmesi. Uluslararası Ĕ̆itim Programları ve Öğretim Çalışmaları Dergisi, 2 (3), 59-72.

Bingölbali, E., Akkoc, H., Özmantar, M.F. ve Demir, S. (2011). Pre-Service and In-Service Teachers' Views of the Sources of Students' Mathematical Difficulties. International Electronic Journal of Mathematics Education, 6, 40-59.

Butler, A. C., Godbole, N., \& Marsh, E. J. (2013). Explanation feedback is better than correct answer feedback for promoting transfer of learning. Journal of Educational Psychology, 105 (2), 290.

Bütün, M., \& Baki, A. (2019). İlköğretim Matematik Öğretmeni Adaylarının Matematiği Öğretme Bilgilerinin Gelişimi. Cumhuriyet Uluslararası Ĕ̆itim Dergisi, 8 (1), 300-322.

Büyüköztürk, Ş., Kılıç-Çakmak, E., Akgün, Ö., Karadeniz, Ş., \& Demirel, F. (2010). Bilimsel araştırma yöntemleri. Pegem akademi: Ankara

Crespo, S. (2000). Seeing more than right and wrong answers: Prospective teachers' interpretations of students' mathematical work. Journal of Mathematics Teacher Education, 3 (2), 155-181.

Çimer, S. O., Bütüner, S. Ö., \& Yiğit, N. (2010). Öğretmenlerin öğrencilerine verdikleri dönütlerin tiplerinin ve niteliklerinin incelenmesi. Uludă̆ Üniversitesi Eğitim Fakültesi Dergisi, 23 (2), 517538 
Franke, M. L., Webb, N. M., Chan, A. G., Ing, M., Freund, D., \& Battey, D. (2009). Teacher questioning to elicit students' mathematical thinking in elementary school classrooms. Journal of Teacher Education, 60(4), 380-392

Genç, G., \& Erdem, A. R. (2016). Matematik Öğretiminde Olumlu Söylem Ortamı ve Söylem Analizi. OPUS Uluslararası Toplum Araştırmaları Dergisi, 6 (10), 200-232.

Kabael, T., \& Ata Baran, A. (2016). Ortaokul matematik öğretmen adaylarının matematiksel söylemleri ve söylem analizleri: fenomenolojik bir araştırma. Journal of international social research, 9 (46).

Köğce, D, Baki, A. (2014). Secondary School Mathematics Teachers' Beliefs About Feedback Concept, Delivery Style and Timing of Feedback. Gaziantep University Journal of Social Sciences, 13 (3), 767-792. DOI: $10.21547 /$ jss.256807

Martino, A. M., \& Maher, C. A. (1999). Teacher questioning to promote justification and generalization in mathematics: What research practice has taught us. The Journal of Mathematical Behavior, 18 (1), 53-78.

McCarthy, P., Sithole, A., McCarthy, P., Cho, J. P., \& Gyan, E. (2016). Teacher Questioning Strategies in Mathematical Classroom Discourse: A Case Study of Two Grade Eight Teachers in Tennessee, USA. Journal of Education and Practice, 7 (21), 80-89.

Moyer, P. S., \& Milewicz, E. (2002). Learning to question: Categories of questioning used by preservice teachers during diagnostic mathematics interviews. Journal of Mathematics Teacher Education, 5(4), 293-315.

Özmantar, M. F., Bingölbali, E., Demir, S., Sağlam, Y., \& Keser, Z. (2009). Değişen öğretim programları ve sinıf içi normlar. Uluslararası İnsan Bilimleri Dergisi 6 (2).

Özmen, Z. M., Taşkın, D., \& Güven, B. (2012). İlköğretim 7. sınıf matematik öğretmenlerinin kullandıkları problem türlerinin belirlenmesi. Eğitim ve Bilim, 37 (165), 246-261.

Schleppenbach, M., Flevares, LM, Sims, LM, Perry, M. (2007a). The answer is only the beginning: Extended discourse in Chinese and US mathematics classrooms. Journal of Educational Psychology, 99 (2), 380-396.

Schleppenbach, M., Flevares, LM, Sims, LM, \& Perry, M. (2007b). Teachers' responses to student mistakes in Chinese and US mathematics classrooms. The elementary school journal, 108(2), 131147.

Sezgin Memnun, D. (2013). Türkiye'deki Cumhuriyet dönemi ilköğretim matematik programlarına genel bir bakış. Mehmet Akif Ersoy Üniversitesi Ĕ̆itim Fakültesi Dergisi, 13 (25), 71 - 91.

Şahin, S. (2011). Öğrenci zorluklarn konusunda geliştirilen bir mesleki gelişim programının matematiksel öğrenci zorluklarına gösterilen öğretmen müdahale türlerine etkisi. Yüksek Lisans Tezi. Gaziantep Üniversitesi, Sosyal Bilimler Enstitüsü, Gaziantep.

Şengül, S., \& Dede, H. G. (2014). Matematik öğretmenlerinin sayı hissi problemlerini çözerken kullandıkları stratejiler. Türk Bilgisayar ve Matematik Eğitimi Dergisi, 5(1), 73-88.

Tanışlı, D. (2013). İlköğretim matematik öğretmeni adaylarının pedagojik alan bilgisi bağlamında sorgulama becerileri ve öğrenci bilgileri, Eğitim ve Bilim, 38 (169), 80-95.

Türkdoğan, A. (2011). Yanlışın Anatomisi: İlköğretim Matematik Sınıflarında Öğrencilerin Yaptıkları Yanlışlar Ve Öğretmenlerin Dönütlerinin Analitik İncelenmesi. Doktora Tezi. Karadeniz Teknik Üniversitesi, Eğitim Bilimleri Enstitüsü, Trabzon

Weinberger, B. (2017). Does It Really Matter What I Ask? How teacher questioning influences the learning of mathematics. Master of education. University of Victoria

Yıldırım, A., Şimşek, H. (2013). Sosyal Bilimlerde Nitel Araştırma Yöntemleri. Ankara: Seçkin Yayıncılık. 